\title{
Zarządzanie głosem w perspektywie edukacyjnej
}

Jednym z największych atutów mówcy podczas wygłaszania mowy jest jego głos. Mówiący powinien wiedzieć, kiedy np. mówić podniesionym głosem, kiedy ściszonym, a kiedy normalnym; poza tym - jakiej użyć tonacji, czy wysokiej, czy niskiej, a także, jaki dostosować rytm do przedmiotu wypowiedzi. Mówca bowiem musi mieć na uwadze trzy rzeczy: siłę głosu, wysokość tonacji i rytm¹. Przytoczona uwaga Arystotelesa dotyczy nie tylko osób występujących publicznie, ale wszystkich, dla których głos jest podstawowym narzędziem pracy.

O skuteczności wygłaszanej wypowiedzi decyduje harmonijne współistnienie trzech kodów: językowego, parajęzykowego i niejęzykowego² [zob. Tabela 1]. „Dobry mówca wie, że poprzez odpowiednie wygłoszenie tekstu można nie tylko przekonać słuchaczy, ale również dostarczyć im wzruszeń i przeżyć natury estetycznej"3.

Tabela 1. Subkody komunikacji słownej

\begin{tabular}{|l|l|}
\hline KOD PODSTAWOWY & KODY SKŁADOWE \\
\hline Językowy & $\begin{array}{l}\text { fonologiczny, morfologiczny, leksykalny, } \\
\text { syntaktyczny, stylistyczny }\end{array}$ \\
\hline
\end{tabular}

* Doktor, Uniwersytet Opolski, Wydział Filologiczny, Instytut Językoznawstwa, Katedra Języka Polskiego, pl. Kopernika 11, 45-040 Opole, atabisz@uni.opole.pl

1 Arystoteles, Retoryka. Retoryka dla Aleksandra. Poetyka, przekł. H. Podbielski, Wydawnictwo Naukowe PWN, Warszawa 2004, s. 172.

2 M. Barłowska, A. Budzyńska-Daca, M. Załęska i in., Ćwiczenia z retoryki, Wydawnictwo Naukowe PWN, Warszawa 2012, s. 365.

3 Tamże, s. 366. 
Tabela 1. (c.d.)

\begin{tabular}{|c|c|c|}
\hline \multicolumn{2}{|c|}{ KOD PODSTAWOWY } & KODY SKŁADOWE \\
\hline \multirow{2}{*}{ Parajęzykowy } & prozodyczny & akcent, intonacja, rytm \\
\hline & paraprozodyczny & ton głosu, brzmienie, tempo mówienia \\
\hline \multicolumn{2}{|l|}{ Niejęzykowy } & $\begin{array}{l}\text { kinezyczny, zapachowy, dotykowy, wzrokowy, } \\
\text { prezencyjny, fizjologiczny, temporalny, } \\
\text { kontekstowy, proksemiczny }\end{array}$ \\
\hline
\end{tabular}

Źródło: oprac. na podstawie propozycji Bożydara Kaczmarka ${ }^{4}$

Słowo mówione silniej niż słowo pisane oddziałuje na odbiorcę, a warstwa parajęzykowa komunikatu wydaje się „prawdziwsza” od językowej, ponieważ nadawca wypowiedzi nie jest w stanie jej całkowicie kontrolować ${ }^{6}$ - wszystko w głosie „mówi”. Wskazuje na to zaproponowana przez Rogera Browna hierarchia kontrowalności komunikatu od najbardziej kontrolowanych zachowań językowych do najbardziej „nieszczelnych” zachowań parajęzykowych pozostających poza kontrolą użytkownika języka. Tezy R. Browna ilustruje Tabela 2.

Tabela 2. Hierarchia kontrowalności komunikatu według R. Browna

\begin{tabular}{|l|l|}
\hline \multicolumn{2}{|l|}{ Zachowania } \\
\hline językowe & \\
\hline \multirow{3}{*}{ niejęzykowe } & mimika twarzy \\
& ciało - ręce - nogi - stopy \\
& właściwości głosu \\
\hline
\end{tabular}

Źródło: na podstawie propozycji Idy $\mathrm{Kurcz}^{\mathbf{7}}$

Świadomość mocy ukrytej w głosie jest podstawą osiągania sukcesu w komunikacji międzyludzkiej. Mówienie z zaangażowaniem, pasją, determinacją i świadomością celu ma znaczny wpływ na słuchacza. Artykuł dotyczy umiejętności zarządzania głosem przez uczniów kończących szkołę średnią. Podstawę materiałową stanowi blisko sto wypowiedzi monologowych formułowanych podczas pilotażowego ustnego egzaminu maturalnego przeprowadzonego w losowo wybranych

4 B. Kaczmarek, Misterne gry w komunikację, wyd. 2, Wydawnictwo UMCS, Lublin 2009, s. 19.

5 J. Apps, Głos perswazji. Jak mówić, aby inni nas słuchali, przekł. L. Śliwa, Wydawnictwo Laurum, Warszawa 2011, s. 21.

6 I. Kurcz, Psychologia języka i komunikacji, Wydawnictwo Naukowe Scholar, Warszawa 2000, s. 195.

7 Tamże, s. 197. 
szkołach ponadgimnazjalnych w roku szkolnym $2011 / 2012^{8}$. Składa się z trzech części. W pierwszej przedstawiam wyniki analiz wypowiedzi przeprowadzonych pod kątem wybranych elementów paralingwalnych mających wpływ na efektywność mówienia. W drugiej przyglądam się treściom kolejnych podstaw programowych [1999, 2002, 2009, 2017] związanych z kształceniem kodu parawerbalnego. W tej części interesuje mnie także przełożenie zapisów programowych na zawartość najnowszych podręczników do nauczania języka polskiego. W ostatniej części staram się wskazać przyczyny nieumiejętnego zarządzania głosem przez młodzież.

\section{Czynniki parajęzykowe a efektywność wypowiedzi maturalnych}

Za czynniki parajęzykowe decydujące o efektywności wypowiedzi uznaję za Jackiem Wasilewskim i Adamem Skibińskim: emocje, pauzę oraz frazowanie? Dzięki właściwemu wykorzystywaniu tych środków słuchacz jest skłonny uznać mówiącego za osobę wiarygodną, przekonującą i kompetentną ${ }^{10}$, a to szczególnie pożądane cechy, jeśli mowa jest o maturzystach zdających ustny egzamin.

Emocje mówiącego świadczą o jego zaangażowaniu w wypowiadaną treśćn ${ }^{11}$. Przekazywane są zarówno za pomocą określonych środków językowych [fonetycznych, morfologicznych, składniowych, leksykalnych], jak i parajęzykowych, takich jak: głośność, ton oraz tempo mówienia.

Głośność uczniowskich wypowiedzi nie budzi zastrzeżeń. Większość badanego materiału charakteryzuje się właściwym [nie za wysokim i nie za niskim] poziomem natężenia głosu. Wypowiadane przez maturzystów słowa są słyszalne, dzięki czemu nie dochodzi do szumów zakłócających komunikację. Jedyna nieprawidłowość występująca w kilkunastu tekstach [niewiele ponad 10 proc.] to stałe, niezmienne natężenie głosu mówiących, przez co wypowiedzi stawały się monotonne, pozbawione jakiejkolwiek dynamiki i ekspresji - trudne w odbiorze. Dłuższego omówienia wymagają dwa pozostałe wyróżniki emocji - ton i tempo mówienia.

Przeżywający stres i tremę maturzyści mają skłonność do mówienia w nieco wyższym rejestrze, ujawniając w ten sposób swoje poddenerwowanie i brak opanowania. W ponad połowie analizowanych wystąpień [55 proc.] linia tonalna jest niedostosowana do przekazywanej treści, uczniowie - wbrew logice i składni zdania - stosują intonację pytającą - „mówią na antykadencji”. Przykładowo:

8 Nagrania zostały udostępnione przez Instytut Badań Edukacyjnych.

9 J. Wasilewski, A. Skibiński, Prowadzeni słowami. Retoryka motywacji w komunikacji publicznej, Difin, Warszawa 2008, s. 237.

10 S.P. Morreale, B.H. Spitzberg, J.K. Barge, Komunikacja niewerbalna, w: tychże, Komunikacja między ludźmi. Motywacja, wiedza i umiejętności, przekł. P. Izdebski, A. Jaworska, D. Kobylińska, Wydawnictwo Naukowe PWN, Warszawa 2007, s. 187.

11 J. Wasilewski, A. Skibiński, Prowadzeni..., s. 238. 
1) yy słowa yy kluczowe to słowa które y są w jakiś szczególny sposób wa... ważne $\uparrow$ ${ }^{12}$ i słowa które mogą o niej wiele powiedzieć $\uparrow$ / na przykładzie słów rosyjskich które odgrywają dużą rolę w kulturze rosyjskiej $\uparrow$ / są one nieocenione $\uparrow$ / jako źródło informacji / są to słowa takie jak dusza tęsknota $\uparrow$ / yy nie istniej... nie istnieje sk... skończony zbiór słów kluczy $\uparrow$ / danej kultury $\uparrow$ / aby ustalić słowa danej kultury $\uparrow$ / ważne jest aby rozważyć różne za i przeciw tego słowa $\downarrow$ /

2) yy/ ja może zacznę że zgadzam się $\uparrow$ / ze stwierdzeniem / Brunona Bettelheima $\uparrow$ / że baśnie odsłaniają wielkie prawdy o człowieku i ludzkości $\uparrow$ / y uważam że $\uparrow$ / na przykład dorośli powinni uczyć się poprzez właśnie baśnie $\uparrow$ / e tak mogą kształtować swoją osobowość $\uparrow$ / y sądzę, że mogą też nie wierzyć, że właśnie baśń może odsłonić prawdę o nich i o ludzkości $\uparrow$ / ale w baśniach uważam że są ukryte alegorie i przenośnie w stosunku właśnie do ludzi $\uparrow / /$

Odbiorca, słysząc nieco wyższy ton na końcu każdej frazy, oczekuje, że mówiący chce coś dodać, uzupełnić swoją wypowiedź. Początkowo zabieg ten może być odebrany przez słuchacza jako wyraz zaangażowania emocjonalnego mówiącego, lecz jeśli wznoszący przebieg linii intonacyjnej charakteryzuje całą wypowiedź, doprowadza to najczęściej do utraty koncentracji i pojawienia się znudzenia u odbiorcy. Nadużywanie antykadencji powoduje, iż wypowiedź nie ma mocy perswazyjnej, a emocje wyrażane w ten sposób przestają być wiarygodne.

Kolejny parametr głosu wymagający komentarza to tempo mówienia ${ }^{13}$, w jakim maturzyści tworzą swoje wypowiedzi. Jerzy Podracki w artykule Jak ocenić ustnq wypowiedź maturalnq... zauważa, że:

W kontaktach oficjalnych [także na maturze] można by oczekiwać wolnego tempa wypowiadania słów [tzw. styl lento], ponieważ wymowa szybka [tzw. styl allegro] często jest nienormatywna. Tempo mówienia jest jednakże sprawą indywidualną, ale w szkole należałoby wdrażać uczniów do «bezpieczniejszego» [wolnego] sposobu wygłaszania tekstu ${ }^{14}$.

12 W zapisie uczniowskich wypowiedzi jeden ukośnik oznacza pauzę trwającą do jednej sekundy, dwa ukośniki - pauzę od jednej do dwóch sekund, trzy ukośniki - pauzę trwającą powyżej dwóch sekund.

13 Zagadnienie to podjęłam już w artykule Czy zmierzch kultury mówienia?..., zob.: A. Tabisz, Czy zmierzch kultury mówienia? - o wybranych cechach ustnych wypowiedzi maturzystów, w: Istnieć w kulturze, istnieć w kulturach: między teoriq a praktyka edukacyjna, red. A. Rypel i D. Jastrzębska-Golonka, Wydawnictwo UKW, Bydgoszcz 2018, s. 186-202.

14 Cyt. za: J. Podracki, Jak oceniać ustna wypowiedź maturalna, czyli o normie językowej w „szkolnym” języku mówionym, „Polonistyka” 2013, nr 10, s. 14-18. 
Badacz odwołuje się do propozycji Władysława Lubasia i Stanisława Urbańczy$\mathrm{ka}^{15}$, którzy wiążą tempo mówienia ze starannością mowy i wyróżniają: a) tempo powolne [lento], uznając je za typ wymowy bardzo starannej; b) tempo umiarkowane [moderato] typowe dla mowy potocznej, jeszcze poprawnej oraz c) tempo szybkie i bardzo szybkie [presto i allegro] charakterystyczne dla mowy niestarannej.

Przyjmuje się, że w naszym kręgu kulturowym szybkość wypowiadania słów mieści się w przedziale od 200 do 500 sylab na minutę. Można zatem założyć, że: a) blisko 200 sylab na minutę charakteryzuje wolną mowę, b) blisko 350 sylab na minutę - względnie „normalną mowę”, c) z kolei blisko 500 sylab odpowiada względnie szybkiej mowie ${ }^{16}$. W znacznej części badanego materiału [ponad 70 proc.] tempo mówienia uczniów nie przekraczało 200 sylab na minutę [przykład 3. - 148 sylab na minutę, przykład 4. - 157 sylab na minutę]:

3) słowo /y jest przedmiotem który w dzisiejszych czasach jest bardzo ważny / za pomocą słowa można doprowadzić do /y wielu /y swoich osiągnięć swoich celów i między innymi stosują to politycy w swoich kampaniach politycznych // za pomocą /y słów / obietnic / starają się przekonać / wyborców o wyższości swojej osoby nad osobą przeciwników /y ważny jest również obraz w dzisiejszych czasach ponieważ / w znaczny sposob oddziaływuje na /y podświadomość odbiorcy /y zarówno słowo jak i obraz jest ważną częścią /reklam ///y [1.oo]

4) [0.20] [...] twórcy reklamy starają się przedstawić swój towar z jak najlepszej strony / podawając jego zalety / bardzo często w reklamach mówią o promocji tego towaru / aby zachęcić klientów do jego kupna / w telewizji emitowane są reklamy które słychać głośniej / na przykład podczas filmu który jest emitowany w danym czasie / starają tak przedstawić swój towar / aby jak najwięcej ludzi do niego sięgło / kupiło go / stosują taki obraz że od razu na pierwszy rzut oka / ludzie jak zobaczą go [...] [1.20]

J. Wasilewski i A. Skibiński podkreślają, że szybkie tempo mówienia świadczy o większym zaangażowaniu emocjonalnym mówcy i utrzymuje zainteresowanie odbiorcy. Potwierdzają to badania amerykańskich psychologów - osoby wypowiadające się wolniej [tempo lento] i z pauzami są mniej przekonujące od osób mówiących szybciej [tempo allegro], których teksty mają większą moc perswazji, są łatwiejsze do zapamiętania i jednocześnie atrakcyjniejsze dla odbiorcy. Odbiorca często bowiem zakłada, że szybkie mówienie charakteryzuje osoby inteligentne, elokwentne i lepiej zorientowane w danej dziedzinie ${ }^{17}$.

15 W. Lubaś, S. Urbańczyk, Podręczny słownik wymowy polskiej, Towarzystwo Miłośników Języka Polskiego, wyd. 2 rozsz., Kraków 1994.

16 Kraków 2005, s. 327.

17 W. Apple, L.A. Streeter, R.M. Krauss, Effects of Pitch and Speech Rate on Personal Attributions, „Journal of Personality and Social Psychology”, 1979, t. 37, nr 5, s. 715-727, http://www.com- 
Wydaje się, że wolna mowa maturzystów wynika z nieprzygotowania przez nich planu semantyczno-syntaktycznego wypowiedzi, o czym świadczą nie tyle błędy językowe, które w odmianie mówionej mogą się zdarzyć, ile nieuporządkowany tok myśli - można odnieść wrażenie, że uczniowie nie wiedzą, co chcą powiedzieć, lub nie są pewni merytorycznej wartości tego, co mówią ${ }^{18}$.

Innym parametrem głosu mającym duże znaczenie dla oddziaływania mowy na słuchacza i świadczącym o zaangażowaniu jest pauza. Dzięki odpowiedniemu stawianiu pauz mówca może panować nad przepływem informacji - dobrze jest, gdy jedna informacja, jedna całostka myślowa pojawia się w zamkniętej frazie. Wyróżnia się dwa rodzaje pauz ${ }^{19}$ - pauzę logiczną, ułatwiającą słuchaczom zrozumienie warstwy tekstowej i interpretację wypowiedzi oraz pauzę psychologiczną, która pełni rolę środka ekspresji ${ }^{20}$ i koncentruje uwagę słuchacza przez działanie na jego sferę emocjonalną ${ }^{21}$. Pauza psychologiczna jako narzędzie wpływania na odbiorcę w ogóle nie jest wykorzystywana przez maturzystów, co wydaje się zrozumiałe ze względu na rozumowy charakter tworzonej wypowiedzi. Z kolei pauzy logiczne, co warto podkreślić, są stosowane przez badanych. Pojawiają się one w strategicznych miejscach wypowiedzi, np.

5) [...] to na przykład nie wiem patriotyzm mógłby mogłabym określić jako słowo kluczowe / gdyż Polska przechodziła w historii dużo przeszła i / walczyła o wolność /// ogólnie mówiąc można dużo takich słów kluczowych w kulturze polskiej/

6) [...] według mnie nie można jednoznacznie odpowiedzieć na pytanie czy druga przestrzeń kompletnie zniknęła z wyobraźni człowieka, ponieważ hyy z jednej strony gdyby tak było / na świecie zapanowałby chaos ludzie pytaliby się o sens życia / nie mieliby do czego dążyć / dlatego ich życie współczesne straciłoby na znaczeniu // z drugiej jednak strony / tak właśnie się dzieje / ponieważ / pojawiają się pojęcia takie jak egzystencjonalizm [...] / dlatego przejdę do dalszej części mojej wypowiedzi ///

municationcache.com/uploads/1/o/8/8/10887248/effects_of_pitch_and_speech_rate_on_ personal_attributions.pdf (dostęp 10.07.2017).

18 Szerzej na ten temat zob.: A. Tabisz, Czy szkoła uczy mówienia? O ustnych wypowiedziach maturzystów, „Polonistyka. Innowacje” 2015, nr 1, s. 54-69, http://pressto.amu.edu.pl (dostęp 2.07.2017) oraz A. Tabisz, Czy zmierzch....

19 Pauza nie jest zjawiskiem jednorodnym ani pod względem formalnym, ani funkcjonalnym. Szeroko na ten temat w: S. Śnatkowski, Milczenie i pauza w gramatyce nadawcy i odbiorcy. Ujęcie lingwoedukacyjne, Wydawnictwo Naukowe Akademii Pedagogicznej, Kraków 2002.

20 M. Barłowska, A. Budzyńska-Daca, M. Załęska i in., Ćwiczenia z retoryki..., s. 419.

21 M. Korolko, Sztuka retoryki. Przewodnik encyklopedyczny, wyd. 2, Wiedza Powszechna, Warszawa 1998, s. 137. 
W przykładach 5. i 6. stosowane przez mówiących nieco dłuższe pauzy sygnalizują pewne operacje logiczne, które pomagają odbiorcy przyjąć odpowiednią strategię interpretacyjną tekstu. Chodzi tu przede wszystkim o stosowanie pauz między poszczególnymi segmentami wywodu argumentacyjnego wypowiedzi. Dzięki ich wprowadzeniu słuchacz otrzymuje wskazania dotyczące funkcjonalnie nacechowanych i wzajemnie zróżnicowanych części składowych wypowiedzi. W przykładzie 5. autor pauzą zapowiada uogólnienie wypowiedzi, co dodatkowo podkreślone jest frazą o charakterze metatekstowym: „ogólnie mówiąc”. W przykładzie 6. pauza podkreśla relację retoryczną zachodzącą między fragmentami tekstu opartą na przeciwstawieniu: „z drugiej strony”.

Cechą szczególną wszystkich analizowanych wypowiedzi to charakterystyczna dla odmiany mówionej pauza redakcyjna, które jest wynikiem niezdecydowania, namysłu ${ }^{22}$. Służy ona psychicznym procesom przygotowania kolejnych fragmentów wypowiedzi. Zdaniem Jean Aitchison tego rodzaju pauzy zajmują około jednej trzeciej wypowiedzi, a w niektórych przypadkach nawet blisko połowę ${ }^{23}$. Potwierdzają to poniższe przykłady:

7) [...] jest też pokazany obraz gdy polewają wodą skacowanych mężczyzn /// [1.44] Inną adaptacją filmową polskiej klasyki literacką literackiej może być Pan Tadeusz / uważam że jest ona dobrze przedstawiona w ofercie dla / klasykę literacką Adama Mickiewicza /// [1.10]

- Dobrze, czy jeszcze coś?

- Nie, dziękuję.

8) Utwór ten w drugiej części to liryka do adresata / podmiot zwraca się bezpośrednio do odbiorcy i utożsamia się z nim / używając / czasowników w trzeciej formie / w pierwszej formie drugiej liczby //[0.17] w ostatniej strofie zwraca się do ludzi mówiąc błagajmy niech nam będzie wrócona druga przestrzeń / podobnie jak w wierszu Ocalony też pragnie by wrócono te wartości // by ludzie się nawrócili /// [1.30]

- To wszystko?

- Tak.

Przykład 7. ilustruje wypowiedź trwającą nieco ponad siedem minut, w której pauzy - momenty milczenia - zajmowały ponad trzy i pół minuty. Najdłuższe przerwy w mówieniu ${ }^{24}$ występują tuż przed „wygaszeniem kontaktu” [przykłady 7. i 8.]. Kończenie wystąpienia dość często sygnalizowane jest przez maturzystów frazami

22 S. Śnatkowski, Milczenie..., s. 20.

23 J. Aitchison, Ssak, który mówi. Wstęp do psycholingwistyki, przekł. M. Czarnecka, Państwowe Wydawnictwo Naukowe, Warszawa 1991, s. 279.

24 Trwające w niektórych przypadkach nawet około czterech minut. 
typu: „nie mam nic więcej do dodania”, „to wszystko”, „i to byłby koniec”, „to chyba wszystko" ${ }^{25}$. Choć pauzy namysłu są typowe dla ustnej odmiany, to jednak przedłużająca się cisza podczas mówienia może zakłócić odbiór i wpłynąć na to, że mówiący będzie odbierany jako niewiarygodny, mający niewiele do powiedzenia. Zastanawiający jest fakt, że uczniowie, mimo iż mają około piętnastu minut na przygotowanie swojej wypowiedzi, nie potrafią z tego czasu efektywnie skorzystać, przez co etapy myślenia, planowania i realizacji warstwy dźwiękowej wygłaszanego tekstu przebiegają równolegle $z$ jego tworzeniem, co pewnie potęguje stres przeżywany przez uczniów podczas egzaminu maturalnego.

Większość pauz namysłu jest wypełniona częściowo lub całkowicie [ponad 95 proc. wypowiedzi]. Forma dźwiękowa wypełnień jest rozmaita, są to m.in. nieartykułowane dźwięki paralingwistyczne - westchnienia, chrząkania - które należy łączyć ze stresem egzaminacyjnym, albo są to dźwięki artykułowane [typu hm, y,e] - mające charakter wykładników kontynuacji wypowiedzi. Innym częstym zjawiskiem w badanym materiale jest nawyk mówiących polegający na wypełnianiu pauz formami językowymi niemającymi semantycznego ${ }^{26}$ uzasadnienia, m.in.: prawda, właśnie, tak, nie, nie wiem, po prostu. Należy jednak podkreślić, że krótkie pauzy wypełnione tylko w nielicznych przypadkach zakłócają odbiór wypowiedzi, czego nie można powiedzieć o zapadającym długim milczeniu.

Pauzy, miejsca, w których zmienia się linia intonacyjna, dzielą wypowiedź na frazy - czyli grupy wyrazów zawierających w sobie jakąś zamkniętą myśl. Fraza da się wróżnić jako element spójny logicznie, oddzielony od kolejnej frazy oddechem $^{27}$. Aby wypowiedź oddziaływała na słuchacza, fraza nie może zamykać się w miejscu nieuzasadnionym, wypowiedź nie powinna być przerwana, jeśli myśl jest niedokończona. Poniższy fragment jest przykładem dość powszechnego zjawiska w badanym materiale nieumiejętnego frazowania:

9) Janusz Wróblewski / napisał recenzję filmu Śluby panieńskie // y prz... w recenzji

tej / y przedstawił kilka swoich / przemyśleń // dotyczących / tego filmu // y zawarł

25 Warto zwrócić uwagę na ostatni przykład: to chyba wszystko, w którym pojawia się partykuta modalna chyba. Używanie jej w wypowiedziach maturalnych wydaje się niezbyt fortunne, ponieważ wyraża ona niepewność i uwydatnia swoisty dysonans poznawczy wyrastający ze świadomości różnicy między wiedzą mówiącego i wiedzą odbiorcy przez co nadawca traci na wiarygodności.

26 Nie zaliczam do tej grupy pauz wypełnionych jednostkami leksykalnymi typu tak pełniącymi funkcję fatyczną.

27 Obok frazy składniowo-logicznej Jerzy Kram wyróżnia frazę emocjonalną charakterystyczną, której celem jest nie tylko aktywizowanie odbiorcy, ale również budzenie jego emocji, J. Kram, Zarys kultury żywego słowa, wyd. 3 popr., Wydawnictwa Szkolne i Pedagogiczne, Warszawa 1981, s. 87. 
/ kilka tez /// y pierwszą taką tezą / jest y / to że / filmowa / ekranizacja Ślubów w reżyserii Filipa Bajona // y jest // zdekonstruowaną wersją zmienioną / y odartą z formy dzieła / Aleksandra Fredry ///y drugą taką tezą jest / y fakt / że / ta filmowa adapt... ekranizacja // y całkiem zmienia oryginalne przesłanie / utworu Fredry o miłości radykalnej i spełnionej // y kolejną taką tezą / myślą / Janusza Wróblewskiego jest /y fakt że odczucie że / ten film miał być komedią a tak naprawdę nią nie jest / brakuje śmiesznych scen // y sceny te są / nieudolne / słabe nie śmieszą i // zniechęcają do tego filmu // y środki językowe / których użył Janusz Wróblewski / w swojej recenzji / to y epitety // hm można tu dos... jest tutaj / dość dużo / y wzbogacają one / y tą recenzję /// y dokładnie potrafią / y dzięki tym epitetom można lepiej wyobrazić sobie / y formułować swoje / przekonanie co do tego filmu /// y dostrzegam też tutaj wyliczenie // y /// no i tyle [2.53]

część fraz stanowi jednostki syntaktyczne, np.: „ten film miał być komedią a tak naprawdę nią nie jest”; „środki językowe / których użył Janusz Wróblewski w swojej recenzji”, lecz większość jest „przypadkowa”, mająca charakter pauz namysłu, np.: „/ y pierwszą taką tezą / jest / to że / filmowa / ekranizacja Ślubów w reżyserii Filipa Bajona”; „/ y prz... w recenzji tej / y przedstawił kilka swoich / przemyśleń / dotyczących / tego filmu /". Pauzy niegramatyczne i niepokrywające się z podziałem wypowiedzi według reguł synatktycznych są typowe dla języka mówionego ${ }^{28}$. Jednak częste stosowanie przez mówiących tego typu przerwań wpływa na to, że szyk składniowy ich wypowiedzi jest bardzo często załamywany, frazy są krótkie, a mowa staje się niepłynna, „telegraficzna” i dość męcząca w odbiorze.

\section{Czynniki parajęzykowe a dokumenty szkolne}

Stopień umiejętności sprawności mówienia, w tym sprawności operowania głosem, jest wynikiem oddziaływania w pierwszej kolejności domu rodzinnego, a następnie szkoły, „której powinnością jest systematyczna i zorganizowana praca nad językiem ojczystym"29. Służą temu m.in. zapisy w dokumentach szkolnych regulujące proces nauczania uczenia się. Obecność treści programowych związanych z rozwijaniem kodu parajęzykowego w zapisach kolejnych podstaw programowych przedstawiona jest w Tabeli 3.

28 S. Śniatkowski, Milczenie..., s. 13.

29 Cyt. za: J. Porayski-Pomsta, Kultura języka, w: Nauka o języku dla polonistów, red. S. Dubisz, wyd. 2 zm. i rozsz., Książka i Wiedza, Warszawa 1996, s. 59. 
Tabela 3. Treści programowe związane z kształceniem kodu parajęzykowego w podstawach programowych nauczania języka polskiego [PP] na kolejnych etapach edukacyjnych

\begin{tabular}{|c|c|c|c|c|c|c|c|c|c|c|c|c|c|c|c|}
\hline \multirow{3}{*}{$\begin{array}{l}\text { Treści programowe } \\
\text { związane } \\
\text { z kodem } \\
\text { parajęzykowym }\end{array}$} & \multicolumn{4}{|c|}{ PP 1999} & \multicolumn{4}{|c|}{ PP 2002} & \multicolumn{4}{|c|}{ PP 2009} & \multicolumn{3}{|c|}{ PP 2017} \\
\hline & \multicolumn{15}{|c|}{ Etapy edukacji } \\
\hline & (a) & II & III & IV & 1 & II & III & $I^{\left.b^{b}\right)}$ & 1 & II & III & IV & 1 & II & $\mathrm{III}^{\mathrm{c})}$ \\
\hline akcent & & $x$ & & $x$ & & $x$ & & $x$ & $x$ & $x$ & & & & $\mathrm{x}$ & \\
\hline intonacja & & $x$ & & $x$ & & $x$ & & $\mathrm{x}$ & $\mathrm{x}$ & $x$ & & & $x$ & $\mathrm{x}$ & \\
\hline rytm & & & & & & & & & & $x$ & $x$ & & & $x$ & \\
\hline ton głosu & & & & & & & & & $x$ & & & $x$ & $x$ & $x$ & \\
\hline brzmienie & $x$ & & & & & & & & & & & & & $x$ & \\
\hline tempo mówienia & & $x$ & & & & $x$ & & & & & & $x$ & $x$ & & \\
\hline pauza & & $x$ & & & & $x$ & & & $x$ & $x$ & & & $x$ & & \\
\hline płynność mówienia & & $x$ & & & & $x$ & & & & & & & $x$ & $x$ & \\
\hline wyrazistość / dykcja & & $x$ & $x$ & & & $x$ & $x$ & $x$ & $x$ & $x$ & & $x$ & $x$ & $x$ & \\
\hline recytacja & $x$ & & $x$ & $x$ & $x$ & & & $\mathrm{x}$ & & $\mathrm{x}$ & $\mathrm{x}$ & & $\mathrm{x}$ & $\mathrm{x}$ & \\
\hline
\end{tabular}

a) Pojęcia: rytm i tempo zostały wprowadzone przy okazji edukacji muzycznej (Dz.U. 1999 nr 14 poz. 129, http://isap.sejm.gov.pl, dostęp 10.08.2017

b) Podstawie programowej nauczania języka polskiego w liceum ogólnokształcącym, liceum profilowanym i technikum [kształcenie w zakresie podstawowym] istnieje zapis: „4)1. [...] niewerbalne środki komunikacji", które obejmują m.in. fonetyczne cechy mówienia. Zaznaczone w tabeli treści pojawiają się przy okazji odbioru dzieł sztuki - punkty 4.1) a) i 4.1) b) (Dz.U. 2002 nr 51 poz. 458, http://isap.sejm.gov.pl, dostęp 10.08.2017).

c) Odwołuję się do projektu Podstawy nauczania języka polskiego w liceum ogólnokształcącym i technikum (zakres podstawowy). Znalazł się w nim następujący zapis: „wygłasza mowę z uwzględnieniem środków pozajęzykowych" (https://men.gov.pl., dostęp 10.08.2017). Trudno ten zapis zinterpretować, ponieważ jedni badacze, m.in. Małgorzata Marcjanik, do środków pozajęzykowych zaliczają jedynie: mimikę, gesty, postawę i ruchy ciała, sposób zagospodarowania przestrzeni, [zob. M. Marcjanik, Grzeczność w komunikacji językowej, Wydawnictwo Naukowe PWN, Warszawa 2007], drudzy również środki parajęzykowe.

Źródło: opracowanie własne

Trudno stwiać hipotezy, dlaczego poszczególne kategorie kodu prozodycznego [akcent, intonacja, rytm] oraz kodu paraprozodycznego [ton głosu, brzmienie, tempo mówienia, pauza] w każdej z podstaw są zaakcentowane w nieco inny sposób. Porównanie zestawionych zapisów pozwala jednak zauważyć, że największa liczba pojęć związanych z kodem parajęzykowym wymieniona jest w podstawie programowej z 2017 r. [na I i II etapie edukacyjnym]. Można więc założyć, że spiralne uporządkowanie treści wpłynie na systematyczność działań nauczycieli oraz uczniów, a także że doskonalenie właściwości suprasegmentalnych języka nie będzie odbywało się jedynie przy okazji wykonywania innych ćwiczeń. 
Choć podstawa programowa jest jednym $\mathrm{z}$ najważniejszych dokumentów szkolnych, to w procesie nauczania uczenia się wciąż równie ważny [jeśli nie ważniejszy] jest podręcznik stanowiący dla nauczyciela swoisty model działania, decydując, czego i w jaki sposób uczyć. Warto więc sprawdzić, czy w nowych podręcznikach dla klas czwartej i siódmej znajdują się zadania, w których kładzie się nacisk na rozwój elementów kodu parajęzykowego [zgodnie z wytycznymi w najnowszej podstawie programowej].

Oba podręczniki NOWE Słowa na start dla klasy czwartej szkoły podstawowej $^{30}$ [dalej NSns 4] i NOWE Słowa na start dla klasy siódmej szkoły podstawowej ${ }^{31}$ [dalej NSns 7] skomponowane są z siedmiu głównych obszarów tematycznych ${ }^{32}$. Każdy z rozdziałów jest podobnie skonstruowany i obejmuje zarówno kształcenie kulturowo-literackie, jak i kształcenie językowe oraz tworzenie wypowiedzi i samokształcenie. Biorąc pod uwagę temat artykułu, uwagę skoncentrowałam przede wszystkim na częściach poświęconych tworzeniu wypowiedzi, założyłam bowiem, że w nich zwłaszcza powinny znaleźć się propozycje zadań doskonalących kod paralingwalny. W NSns 4 podrozdziałach zatytułowanych Szkoła mówienia i pisania porusza się następujące tematy: Jak napisać życzenia lub pozdrowienia?; Od akapitu do tekstu. Jak napisać list?; Jak opisać postać?; Jak opisać przedmiot?; Jak napisać plan wydarzeń?; Jak napisać zaproszenie; Jak napisać opowiadanie? NSns 7 z kolei uwzględnia takie tematy, jak: Jak budować akapity i budować tekst, Jak uzasadnić swoje zdanie; Opis sytuacji, przeżyć wewnętrznych i dzieła sztuki; Charakterystyka; Wypowiedź argumentacujna; Rozprawka; Jak prowadzić dyskusję; Wywiad, Prezentacja. Częste użycie operatora: „napisać” [zwłaszcza w NSns 4] sugeruje, że autorzy podręcznika kładą nacisk przede wszystkim na doskonalenie odmiany pisanej języka, na co zwracała uwagę Maria Nagajowa w Kształceniu języka ucznia w szkole podstawowej:

Kształcenie odmiany pisanej języka jest głównym obowiązkiem nauczyciela polonisty. Odmianę mówioną doskonali bowiem uczeń nie tylko na lekcjach języka polskiego, ale każdego innego przedmiotu. Rozmawia również poza szkołą, wchodząc w różnorakie interakcje społeczne, tym rozleglejsze, im bardziej dorośleje.

30 A. Klimowicz, M. Derlukiewicz, NOWE Stowa na start! Podręcznik do języka polskiego dla klasy czwartej szkoły podstawowej, Nowa Era, Warszawa 2017.

31 J. Kościerzyńska, M. Chmiel, M. Szulc, A. Gorzałczyńska-Mróz, NOWE Słowa na start! Podręcznik do języka polskiego dla klasy siódmej szkoły podstawowej, Nowa Era, Warszawa 2017.

32 W klasie czwartej uwzględniono takie pola tematyczne, jak: 1. Mój dom, moi najbliżsi; 2. Szkolne radości; szkolne smutki; 3. O sobie, o nas; 4. Opisać Polskę; 5. Baśniowe krainy; 6. Co jest w życiu ważne; 7. Urok i siła marzeń oraz dwie dodatkowe części Kartki z kalendarza i Twój niezbędnik, z kolei w klasie siódmej: 1. Oblicza miłości; 2. Pochwała życia; 3. Charaktery; 4. Ojczyzna; 5. Wyobraźnia; 6. Dobro i zło; 7. Nadzieja. 
Odmianę pisaną natomiast poznaje i kształci tylko w szkole, a świadomie ją rozwija jedynie na lekcjach języka polskiego ${ }^{33}$.

Trudno nie zgodzić się ze stanowiskiem badaczki, a tym samym propozycjami autorów podręczników, wydaje się jednak, że w obecnej sytuacji językowo-kulturowej, dla której typowymi zjawiskami są m.in.: „bylejakość mówienia”, prymitywizacja i wulgaryzacja języka, powiększanie się liczby użytkowników władających kodem ograniczonym, systematyczne i systemowe kształcenie sprawności mówienia z uwzględnieniem kodu paralingwalnego jest wręcz konieczne.

Nawet w rozdziałach, w których „mówioność” jest zaznaczona choćby poprzez obecność nazw gatunków funkcjonujących przede wszystkim w sferze mówionej, np. Jak prowadzić dyskusję, Prezentacja, Wywiad, liczba zadań uwzględniających sposób mówienia jest niewielka. Jedynie w podrozdziale Prezentacja pojawiają się zadania, w których akcentuje się wybrane elementy warstwy parawerbalnej. Przykładowo:

Podzielcie się na grupy. Każdy w zespole ma za zadanie opowiedzieć o swoich zainteresowaniach przez ok. 3 minuty. W tym czasie pozostałe osoby uważnie słuchają i analizują formę wypowiedzi: jej głośność, tempo, płynność, umiejętne stosowanie pauz [NSns 7, s. 320]

Przeczytaj wiersz głośno i wyraźnie [NSns 7, s. 320 ${ }^{34}$

Na doskonalenie elementów paralingwalnych [intonacji wymowy, akcentu wyrazowego i pauzy] zwraca się uwagę także w nielicznych zadaniach znajdujących się w rozdziałach z nauki o języku. W NSns 4 w części dotyczącej zdań oznajmujących, pytających i rozkazujących, a w NSns 7 w częściach poświęconych fonetyce i akcentowi. Przykładowo:

„Przeczytaj głośno tekst piosenki. Odszukaj w nim wyrazy, które utraciły dźwięczność przed pauzą (na końcu wersu lub przed przecinkiem). Ich liczba wskaże Ci wykonawcę utworu [...]" [NSns 7, s. 51].

33 M. Nagajowa, Kształcenie języka ucznia w szkole podstawowej, Wydawnictwa Szkolne i Pedagogiczne, Warszawa 1985, s. 20.

34 Warto odnotować, że teksty poetyckie zamieszczone w analizowanych podręcznikach prawie w ogóle nie są opatrzone poleceniami zawierającymi wskazówki dotyczące interpretacji głosowej. Pojawiają się pojedyncze zadania, w których proponuje się wygłoszenie utworu poetyckiego, np.: „Zorganizujcie w klasie konkurs na najciekawszą recytację poniższego wiersza” (NSns 7, s. 49). 
„Wskaż rzeczowniki, w których akcent pada na 3. sylabę od końca. Przeczytaj poprawnie te wyrazy [...]" [NSns 7, s. 90].

Z perspektywy szkolnego procesu nauczania uczenia się istotne jest to, aby wiedza o języku przekładała się na praktykę językową, na wykonania językowe ucznia, czyli na kompetencję komunikacyjnojęzykową, ponieważ, jak zauważa Hanna Komorowska

Ucząc systemu językowego, cały czas należy pamiętać o tym, że poszczególne formy i struktury nie są celem samoistnym, ale służą do przenoszenia pewnych treści i to właśnie komunikacja jest ostatecznym celem nauki, to umiejętność porozumiewania się jest rzeczywistym punktem docelowym, a środki językowe to jedynie niezbędny warunek wytyczonego w ten sposób celu ${ }^{35}$.

Założenie to rzadko jest realizowane w nowych podręcznikach. Proponowane zadania najczęściej realizują funkcjonalność wenątrzsysemową. Trudno więc mówić o funkcjonalnym i praktycznym rozwijaniu sprawności mówienia - w tym warstwy paralingwalnej.

\section{Skąd uczniowskie kłopoty w zarządzaniu głosem?}

Analiza wypowiedzi pokazuje, że wielu uczniów nie potrafi właściwie zarządzać głosem, ma kłopot z prawidłowym stosowaniem pauzy, płynnością wypowiedzi, właściwym frazowaniem i mówieniem w odpowiednim tempie. Wydaje się, że maturzyści w ogóle nie mają świadomości, iż odpowiednie operowanie głosem wpływa na odbiór tego, co mówią, i na postrzeganie ich samych.

Mechanizm powstawania przedstawionych usterek jest bardzo złożony. Biorąc pod uwagę to, że wypowiedzi powstały podczas egzaminu, można uznać, że częstą przyczyną powstawania błędów jest stres wpływający na ograniczenie autokontroli mówiącego. Zdaniem Józefa Porayskiego-Pomsty działa on tym mocniej, im niższy jest poziom wiedzy wyraźnej, a także gdy język literacki / ogólny jest opanowywany przez użytkownika języka nie w sposób naturalny w procesie socjalizacji, lecz w szkole poprzez metajęzyk ${ }^{36}$.

Zakładam też, że wielu nauczycieli [zwłaszcza nie polonistów] nie przywiązuje dostatecznej wagi do kształcenia języka mówionego i elementów paralingwalnych. Wśród „grzechów” szkoły przeciwko rozwijaniu sprawności mówienia obok częstego stosowania strategii asocjacyjnej; stosowania na lekcjach pogadanki

35 H. Komorowska, Ćwiczenia komunikacyjne w nauce języka obcego, Wydawnictwa Szkolne i Pedagogiczne, Warszawa 1988, s. 31.

36 J. Porayski-Pomsta, Kultura..., s. 91. 
heurystycznej nastawionej głównie na aktywność nauczyciela; należy wymienić niefunkcjonalne podejście do gramatyki oraz niewielką liczbę zadań „na mówienie" w podręcznikach do nauczania języka polskiego ${ }^{37}$, a także takich, które pomogłyby uczniom opanować stres, tremę podczas wystąpień publicznych. Istotna jest również postawa użytkownika języka wobec samego języka. Obecna „pragamtyzacja języka" - widzenie w nim wyłącznie narzędzia wspomagającego skuteczną komunikację - sprawia, że przestaje być wartością dla jednostki, co zwalnia ją z estetycznego mówienia. Szkoła nie jest jednak bezradna wobec owych zjawisk. Zdaniem Agnieszki Rypel, wykształcenie uczniowskich postaw wobec języka $\mathrm{w}$ procesie nauczania uczenia się jest możliwe do osiągnięcia poprzez realizowanie w szkole sfunkcjonalizowanej wiedzy językowej oraz doskonalenie różnego typu umiejętności na poziomie języka, poziomie komunikacji interpersonalnej oraz na poziomie komunikacji kulturowej ${ }^{38}$.

\section{Bibliografia}

Aitchison Jean, Ssak, który mówi. Wstęp do psycholingwistyki, przekł. Maria Czarnecka, Państwowe Wydawnictwo Naukowe, Warszawa 1991.

Apple William, Streeter Lynn A., Krauss Robert M., Effects of Pitch and Speech Rate on Personal Attributions, "Journal of Personality and Social Psychology" 1979, t. 37, nr 5, s. 715-727, http://www.communicationcache.com/uploads/1/0/8/8/10887248/effects_of_pitch_and_speech_rate_on_personal_attributions.pdf (dostęp 10.07.2017).

Apps Judy, Głos perswazji. Jak mówić, aby inni nas stuchali, przekł. Leszek Śliwa, Wydawnictwo Laurum, Warszawa 2011.

Arystoteles, Retoryka. Retoryka dla Aleksandra. Poetyka, przekł. Henryk Podbielski, Wydawnictwo Naukowe PWN, Warszawa 2004.

Barłowska Maria, Budzyńska-Daca Agnieszka, Załęska Maria i in., Ćwiczenia z retoryki, Wydawnictwo Naukowe PWN, Warszawa 2012.

Kaczmarek Bożydar, Misterne gry w komunikację, wyd. 2, Wydawnictwo UMCS, Lublin 2009.

37 Szerzej na ten temat zob.: A. Tabisz, Siedem grzechów głównych przeciwko rozwijaniu sprawności mówienia w szkole, w: W krajobraz literacko-kulturowy i językowy wpisane...: Księga jubileuszowa dedykowana profesor Bernadecie Niesporek-Szamburskiej w czterdziestolecie pracy naukowej i dydaktycznej, red. A. Guzy, D. Krzyżyk, M. Ochwat, M. Wójcik-Dudek, Prace Naukowe Uniwersytetu Śląskiego w Katowicach, nr 3668, Wydawnictwo UŚ, Katowice 2018, s. 285-297.

38 A. Rypel, Wychowanie językowe, czyli jak scalić rozproszona świadomość językowa, w: Język a Edukacja 3: Świadomość językowa, red. J. Nocoń, A. Tabisz, Wydawnictwo UO, Opole 2014, s. 53-65. 
Klimowicz Anna, Derlukiewicz Marlena, NOWE Stowa na start! Podręcznik do języka polskiego dla klasy czwartej szkoły podstawowej, Nowa Era, Warszawa 2017. Komorowska Hanna, Ćwiczenia komunikacyjne w nauce języka obcego, Wydawnictwa Szkolne i Pedagogiczne, Warszawa 1988.

Korolko Mirosław, Sztuka retoryki. Przewodnik encyklopedyczny, wyd. 2, Wiedza Powszechna, Warszawa 1998.

Kościerzyńska Joanna, Chmiel Małgorzata, Szulc Maciej, Gorzałczyńska-Mróz Agnieszka, NOWE Słowa na start! Podręcznik do języka polskiego dla klasy siódmej szkoły podstawowej, Nowa Era, Warszawa 2017.

Kram Jerzy, Zarys kultury żywego słowa, wyd. 3 popr., Wydawnictwa Szkolne i Pedagogiczne, Warszawa 1981.

Kurcz Ida, Psychologia języka i komunikacji, Wydawnictwo Naukowe Scholar, Warszawa 2000.

Lubaś Władysław, Urbańczyk Stanisław, Podręczny słownik wymowy polskiej, wyd. 2 rozsz., Towarzystwo Miłośników Języka Polskiego, Kraków 1994.

Marcjanik Małgorzata, Grzeczność w komunikacji językowej, Wydawnictwo Naukowe PWN, Warszawa 2007.

Morreale Sherwyn P., Spitzberg Brian H., Barge J. Kevin, Komunikacja niewerbalna, w: Morreale Sherwyn P., Spitzberg Brian H., Barge J. Kevin, Komunikacja między ludźmi. Motywacja, wiedza i umiejętności, przekł. Paweł Izdebski, Aleksandra Jaworska, Dorota Kobylińska, Wydawnictwo Naukowe PWN, Warszawa 2007.

Nagajowa Maria, Kształcenie języka ucznia w szkole podstawowej, Wydawnictwa Szkolne i Pedagogiczne, Warszawa 1985.

Podracki Jerzy, Jak oceniać ustna wypowiedź maturalna, czyli o normie językowej w „szkolnym” języku mówionym, „Polonistyka” 2013, nr 10, s. 14-18.

Podstawa programowa nauczania języka polskiego w liceum ogólnokształcacym, liceum profilowanym i technikum (kształcenie $w$ zakresie podstawowym), https:// men.gov.pl (dostęp 10.08.2017).

Porayski-Pomsta Józef, Kultura języka, w: Nauka o języku dla polonistów, wyd. 2 zm. i rozsz., red. Stanisław Dubisz, Książka i Wiedza, Warszawa 1996.

Rypel Agnieszka, Wychowanie językowe, czyli jak scalić rozproszona świadomość językowa, w: Język a Edukacja 3: Świadomość językowa, red. Jolanta Nocoń, Anna Tabisz, Wydawnictwo UO, Opole 2014, s. 53-65.

Sikorski Wiesław, Gesty zamiast słów: psychologia i trening komunikacji niewerbalnej, Impuls, Kraków 2005.

Śniatkowski Sławomir, Milczenie i pauza w gramatyce nadawcy i odbiorcy. Ujęcie lingwoedukacyjne, Wydawnictwo Naukowe Akademii Pedagogicznej, Kraków 2002.

Tabisz Anna, Czy szkoła uczy mówienia? O ustnych wypowiedziach maturzystów, „Polonistyka. Innowacje” 2015, nr 1, s. 54-69, http://pressto.amu.edu.pl (dostęp 10.08.2017). 
Tabisz Anna, Czy zmierzch kultury mówienia? - o wybranych cechach ustnych wypowiedzi maturzystów, w: Istnieć $w$ kulturze, istnieć $w$ kulturach: między teoria a praktyką edukacyjna, red. Agnieszka Rypel i Danuta Jastrzębska-Golonka, Wydawnictwo UKW, Bydgoszcz 2018.

Tabisz Anna, Siedem grzechów głównych przeciwko rozwijaniu sprawności mówienia w szkole, w: W krajobraz literacko-kulturowy i językowy wpisane...: Ksiega jubileuszowa dedykowana profesor Bernadecie Niesporek-Szamburskiej w czterdziestolecie pracy naukowej i dydaktycznej, red. Anna Guzy, Danuta Krzyżyk, Magdalena Ochwat, Małgorzata Wójcik-Dudek, Prace Naukowe Uniwersytetu Śląskiego w Katowicach, nr 3668, Wydawnictwo UŚ, Katowice 2018, s. 285-297.

Wasilewski Jacek, Skibiński Adam, Prowadzeni słowami. Retoryka motywacji w komunikacji publicznej, Difin, Warszawa 2008.

Anna Tabisz

\title{
Zarządzanie głosem w perspektywie edukacyjnej
}

\author{
Streszczenie
}

Artykuł dotyczy umiejętności zarządzania głosem przez uczniów kończących szkołę średnią i składa się z trzech części. W pierwszej przedstawiam wyniki analiz wypowiedzi przeprowadzonych pod kątem wybranych elementów paralingwalnych mających wpływ na efektywność wypowiedzi (natężenie głosu, ton, tempo mówienia oraz pauzę i frazowanie). W drugiej części przyglądam się treściom kolejnych podstaw programowych $(1999,2002,2009,2017)$ poświęconym zagadnieniom związanych z kształceniem kodu parawerbalnego. W tej części interesuje mnie zwłaszcza przełożenie zapisów programowych na zawartość najnowszych podręczników do nauczania języka polskiego. W ostatniej części artykułu - mającej charakter podsumowania - szukam odpowiedzi na pytanie, dlaczego tak wielu uczniów nie potrafi właściwie zarządzać swoim głosem.

Słowa kluczowe: głos, zarządzanie głosem, kod parawerbalny, edukacja. 


\section{Voice management from an educational point of view}

Summary

The article focuses on the voice management skills in secondary school graduates. It consists of three parts. Part one is a presentation of the results of analyses of statements with respect to selected paralingual elements influencing the effectiveness of a statement (such as voice intensity, tone, speaking tempo, pausing and phrasing). Part two is an analysis of the core curricula (of 1999, 2002, 2009, 2017) related to the aspects of developing the paraverbal code. Emphasis is put in this part on how the content of the core curricula is incorporated in the latest Polish language teaching handbooks. In the final part of the article - a summary - I attempt to find an answer to the following question: why are so many pupils not able to properly manage their voice?

Keywords: voice, voice management, paraverbal code, education.

Anna Tabisz, dr, lingwodydaktyczka, językoznawczyni, adiunkt w Katedrze Języka Polskiego w Instytucie Językoznawstwa Uniwersytetu Opolskiego. Zainteresowania badawcze mieszczą się w obrębie: lingwodydaktyki, lingwistyki tekstu, pragmalingwistyki, psycholingwistyki oraz glottodydaktyki. Problemy szczegółowe, które podejmuje w badaniach własnych, to: komunikacja dydaktyczna, kształcenie językowe w szkole, sprawność mówienia ucznia. Autorka Kompetencji tekstotwórczych uczniów na przykładzie rozprawki oraz licznych artykułów naukowych. Redaktorka i współredaktorka tomów z serii „Język a Edukacja”. Członkini państwowej komisji certyfikatowej z języka polskiego jako obcego. 